\title{
Violències, marginalitats i dones en la Corona d'Aragó: una aproximació documental i literària
}

\author{
Violence, marginality and women in the Crown of Aragon: a \\ documentary and literary approach
}

\author{
Alejandro Llinares Planells \\ a.llinares@uma.es \\ Universidad de Málaga \\ Jacob Mompó Navarro \\ jacob.mompo@ucv.es \\ Universitat Catòlica de València
}

L'estudi de textos marginals, escrits confeccionats al marge de la història i la literatura, permet traure a la llum circumstàncies i vides de persones anònimes, històries sovint silenciades pels discursos oficials que se centren, majoritàriament, en l'estudi de persones riques, blanques i heterosexuals vinculades directament o indirecta als cercles de poder. Capbussats entre la documentació d'arxiu, però també en textos amb voluntat literària, hom pot trobar històries relacionades amb la vida marginal de prostitutes, bandits, bruixes, criminals, lladres, fetilleres, homosexuals o integrants de distintes minories ètniques i religioses, entre d'altres. Al llarg de la història, les dones han estat considerades un ésser inferior. I les dones que formaren part d'aquests col lectius marginals foren, doncs, doblement marginades: per la seua condició de prostituta, de fetillera, de jueva, etc., i per dona.

La tradició judeocristiana, fonamentada en l'essència emanada del llibre revelat, però també construïda entorn a la literatura patrística, va contribuir a perpetuar una imatge negativa de la dona, sotmesa i dominada. Ella era l'origen del pecat i era concebuda com un ésser lasciu, voluble i propens a caure en les xarxes del desig i les pulsions humanes. Es tractava, doncs, d'un element capaç de desestabilitzar la societat i que calia dominar amb la supervisió d'un home: pare, germà o marit. La Bíblia remarcava la seua condició, com a dominada: «Et faré patir les grans fatigues de l'embaràs i donaràs a llum enmig de dolors. Desitjaràs el teu home, i ell et voldrà dominar» (Gn 3, 36), o com a propietat: «No desitges la casa d'un altre. No desitges la seua dona, ni el seu esclau, ni la seua esclava, ni el seu bou, ni el seu ase, ni res del que li pertany» (Ex 20,17). 
Alejandro Llinares Planells \& Jacob Mompó Navarro. Violències, marginalitats i dones en la Corona d'Aragó: una aproximació documental i literària

No obstant això, el text bíblic està farcit de dones virtuoses o exalçades per la tradició, fins i tot dones dels estrats més humils o col lectius marginats. Posem per exemple el cas de Rahab, prostituta de Jericó que va allotjar dos espies enviats per Josué durant les campanyes de conquesta del regne de Canaan (Js 2). Les seues actuacions en aquell episodi van permetre el canvi de tractament que rebria en diferents passatges bíblics, de prostituta a reverenciada (Js 6, 25), fins al punt de passar a formar part de la genealogia de Jesús que ofereix l'Evangeli de Mateu (Mt 1, 5). En el cas concret de la Bíblia cristiana, el paradigma de la virtut el reencarna Maria, la mare de Déu. Però en la tradició van pesar més els passatges que, contra la dona, contenien les connotacions més negatives. Moralistes com el valencià Lluís Vives, en la seua obra De officio mariti (1529), culpaven directament les dones, adduint la seua falta de decència. Entre altres afirmacions, Vives expressava que havien de ser les esposes les que garantien una harmonia marital; així doncs, si el marit tenia una reacció violenta envers la seua muller, aquesta esdevenia l'única responsable a causa del seu mal comportament o excés.

Quan una dona maltractada, físicament o psicològica, buscava posar solució a la seua situació, la primera reacció no era acudir a les autoritats: més bé al contrari. La denúncia pública era, en la majoria dels casos, l'últim recurs davant un context quasi dramàtic per a la víctima. En molts casos la muller se sentia avergonyida per la situació i preferia no traure a la llum els seus problemes. A més, les dones estaven enormement influenciades per la mentalitat que l'església, àmpliament difosa per moralistes i predicadors, que premiava el model de la dona pacient que havia d'intentar comprendre a la part masculina i provar de -si arribava el moment-, suavitzar els impulsos violents dels homes. Aleshores, malgrat que la violència contra les dones fou, i encara ho és, una realitat quotidiana, els documents que ens parlen sobre el tema no deixen de representar una part minoritària del total, aquelles poques dones que acudiren o foren portades davant la justícia, però l'estudi i l'anàlisi d'aquestes fonts ens mostra un percentatge, encara que minoritari, representatiu, d'aquesta quotidianitat silenciada.

En aquest dossier d'Scripta parlarem, doncs, de la violència, la dominació i la marginalitat a què van haver de fer front les dones durant les edats mitjana i moderna a través d'escrits confeccionats en territoris de la Corona d'Aragó. I, encara, des de dos vessants. D’una banda, amb aportacions basades en l'estudi de textos literaris, com ara les diverses concepcions del persontage de Griselda, prototipus de dona maltractada psicològicament; o la visió de la dona en els textos dramàtics de Francesc Palanca i Roca, on es reflecteixen imatges burlesques, iròniques i masclistes que beuen de la traició literària misògina. De l'altra, amb estudis de recerca documental, com l'intercanvi epistolar entre Maria de Castella i Beatriu Martí, que constata la violència domèstica també en nuclis familiars benestants; documentació diversa que reflecteix les relacions entre música, ball i prostitució; l'emprempta de la violència física en els cossos de les dones; la violència, en aquest cas econòmica, exercida contra les dones mallorquines del segle XVII o el menysteniment de la societat envers les dones i mares solteres.

Així doncs, obri aquest monogràfic l’aportació de Júlia Butinyà, que ens ofereix una anàlisi sobre l'evolució del tractament que ha tingut una figura literària, Griselda, paradigma de dona maltractada 
Alejandro Llinares Planells \& Jacob Mompó Navarro. Violències, marginalitats i dones en la Corona d'Aragó: una aproximació documental i literària

psicològicament. En primer lloc, el canvi que produí en la Griselda de Bocacció, vista com una crítica al marit psicològicament maltractador, la traducció llatina de Petrarca, que revestí el relat amb una capa religiosa, tot divinitzant el marit. La transmissió del relat en català la devem a Metge, el qual, malgrat partir de la versió llatina de Petrarca, situà Griselda en un lloc més digne. Però després de Metge, no s'aprecia aquesta dignificació en la difusió de l'obra arreu les literatures europees.

Per la seua banda, Anastasia Terzopoulou realitza un estudi comparatiu entre dues dones, espacialment i temporalment allunyades, com foren Andròmaca i la noble valenciana Beatriu Martí, però a qui els unien una vida caracteritzada pel sofriment, l'angoixa, el maltracte i la injustícia que contra elles es cometé. Andròmaca, esposa de l'hereu de Troia, arran la caiguda de la ciutat es convertí en esclava i concubina del seu captor. D'altra banda, l'autora detalla les desventures de Beatriu Martí a través d'unes cartes de la reina d'Aragó, Maria de Castella, en què exortava el marit de Beatriu que cessara el maltracte contra la noble.

Seguidament, Raül Sanchis estudia les relacions existents entre el ball i la prostitució en els darrers anys de l'edat mitjana, una època en què la prostitució estava vista com un mal menor, malgrat els teòlegs i els predicadors, que blasmaven contra aquesta pràctica. D’aquesta manera, el bordell de València es convertí en un dels més grans de tot Europa. Dins l'estudi de Sanchis, destaquen les sabies, marginades per la seua condició de dones, musulmanes i prostitutes.

En l'article signat per Carmel Ferragut i Guillem Roca s'analitza el maltracte físic contra les dones a finals de l'edat mitjana, des del punt de vista de les petjades que la violència provocava en els seus cossos, a partir d'una documentació nombrosa, provinent, sobretot, d'arxius de València i de Lleida. El treball posa de manifest, tant les actuacions fetes en primera instància per tal de guarir les dones víctimes de violència, com, també, les investigacions pericials posteriors per intentar esclarir els fets. Es tracta d'una visió de la realitat més crua, més brutal, la de les ferides com a imatge i mostra de les condicions que van haver de suportar moltes dones durant el període estudiat.

Per la seua part, Victòria Nicolau Bauçà ens parla de la violència exercida contra les dones en la Mallorca del segle XVII; una violència que no solament es donava en l'àmbit familiar, sinó també fora de la llar. La justificació moral que permetia aquest tracte envers la dona rau en la concepció de la violència permesa contra un subjecte, la dona, a qui s'havia de castigar davant el més mínim desviament de la conducta que se li pressuposava. Però aquesta violència no era únicament física, sinó també d’altres tipologies. No cal dir que la violència física és aquella que crida més l'atenció, però no era l'única forma d'exercir l'opressió envers la dona. En el seu article, Nicolau s'hi centra en la violència econòmica com una de les violències segurament no tant perceptibles, però, sense dubte, la més habitual. I així, analitza nombrosa documentació de l'àmbit judicial, tant de la justicia criminal com de la civil, i també diversos documents juridicoadministratius per constatar la violència contra les dones al segle XVII com un problema estructural i la privació de l'administració dels seus béns com un mètode que reforçava el control, tant social com econòmic, de l'home sobre la dona. 
Jacob Mompó, per una altra banda, recupera un procés inquisitorial dels darrers temps de la inquisició (1804) contra una dona, Àgueda Guimerà, que fou vista pels seus veïns com una dona de conducta moralment reprovable pel fet de ser dona, soltera i mare d'un fill nascut al marge de la institució matrimonial. El procés analitzat recull les cartes que el pare espiritual de la població d'Ortells, Felicio Esteller, envià al Tribunal de la Inquisició de València, en què explicava un seguit de calúmnies que la dona blasmava contra ell. Aquestes cartes, però, semblen estar redactades com a moviment preventiu davant una amenaça imminent de denúncies pel delicte de sol licitació.

Finalment, Hilari Garcia aporta una anàlisi sobre la sàtira misògina en els textos teatrals del dramaturg valencià del segle XIX Francesc Palanca i Roca. L'article reflexiona sobre la càrrega cultural que, per al sociòleg, per a l'historiador i per al filòleg tenen els textos dramàtics del segle XIX i analitza el lèxic i els tòpics misògins heretats de la tradició literària en un abundant corpus teatral de de l'obra de Palanca i Roca. 